\title{
Pengaruh Air Gap Terhadap Unjuk Kerja Motor Brushless Direct Current 3 Fasa Fluks Aksial Stator Ganda
}

\author{
Bella Octavia Nurul Hidayah ${ }^{1}$, Widyono Hadi ${ }^{2}$, Widya Cahyadi ${ }^{3}$ \\ [Submission: 09-09-2020, Accepted: 10-12-2020]
}

\begin{abstract}
Between the stator and rotor there is a gap called the air gap. In BLDC motors, air gaps can affect motor speed and motor torque. The purpose of this study is to determine the effect of the air gap on the speed and torque produced by the BLDC 3 phase double stator axial flux motor. Tests are carried out at $4 \mathrm{~mm}$ and $5 \mathrm{~mm}$ air gap, when the motor is not overloaded and when the motor is loaded, at a source voltage of $12 \mathrm{~V}-15 \mathrm{~V}$. The results of testing on the motor are not burdened, ie when the source voltage is increased, the voltage, current, frequency, speed, motor power and torque increase. At a $5 \mathrm{~mm}$ water gap, the results of the voltage, frequency and speed have a greater value than the $4 \mathrm{~mm}$ water gap. While the results of the motor current, motor power and torque have a smaller value than the 4 mm air gap. The results of the motorized test are when the load and source voltage are increased, the motor voltage, frequency and speed increase. While the current, power and torque of the motor decreases. At the $4 \mathrm{~mm}$ water gap, the results of the voltage, frequency and speed of the motor have a greater value than the $5 \mathrm{~mm}$ water gap. While the current, power and torque of the motor have a smaller value than the $5 \mathrm{~mm}$ air gap.
\end{abstract}

Intisari- Diantara stator dan rotor terdapat celah yang disebut celah udara (air gap). Pada motor BLDC celah udara dapat mempengaruhi kecepatan motor dan torsi motor. Tujuan penelitian ini yaitu untuk mengetahui pengaruh air gap terhadap kecepatan dan torsi yang dihasilkan oleh motor BLDC 3 fasa fluks aksial stator ganda. Pengujian dilakukan pada air gap 4 mm dan $5 \mathrm{~mm}$, ketika motor tidak berbeban dan ketika motor diberi beban, pada tegangan sumber sebesar 12V - 15V. Hasil pengujian pada motor tidak berbeban yaitu ketika tegangan sumber dinaikkan, maka tegangan, arus, frekuensi, kecepatan, daya motor dan torsi meningkat. Pada air gap $5 \mathrm{~mm}$, hasil dari tegangan, frekuensi dan kecepatan memiliki nilai yang lebih besar dibandingkan pada air gap $4 \mathrm{~mm}$. Sedangkan hasil dari arus motor, daya dan torsi motor memiliki nilai yang lebih kecil dibandingkan pada air gap $4 \mathrm{~mm}$. Hasil pengujian motor berban yaitu ketika beban dan tegangan sumber dinaikkan, maka tegangan, frekuensi dan kecepatan motor meningkat. Sedangkan arus, daya dan torsi motor menurun. Pada air gap $4 \mathrm{~mm}$, hasil dari tegangan, frekuensi dan kecepatan motor memiliki nilai yang lebih besar dibandingkan pada air gap 5 mm. Sedangkan arus, daya dan torsi motor memiliki nilai yang lebih kecil dibandingkan pada air gap 5 mm.

\footnotetext{
${ }^{1}$ Mahasiswa, Jurusan Teknik Elektro Fakultas Teknik Uviversitas Jember, Tukum, Tekung Lumajang, 67381 (Hp: 082228007388; e-mail: bellaoctavia23nurulhidayah@gmail.com)

2, 3 Staf Pengajar, Jurusan Teknik Elektro Fakultas Teknik Uviversitas Jember, Kampus Tegalboto, Jl. Kalimantan No.37, Krajan Timur, Sumbersari, Kec. Sumbersari, Kabupaten Jember, Jawa Timur 68121 (e-mail: widyono.hadi1961@gmail.com, email:cahyadi@unej..ac.id)
}

Kata Kunci-air gap, motor bldc, fluks aksial, stator ganda.

\section{PENDAHULUAN}

Motor listrik termasuk salah satu perangkat listrik yang digunakan dalam kehidupan sehari-hari. Sifat umum motor listrik yaitu semua motor listrik bekerja dengan menggunakan hukum elektromagnetik [1]. Motor BLDC merupakan motor listrik sinkron AC 3 fasa. Disebut dengan motor BLDC karena pada implementasinya menggunakan tegangan DC sebagai sumber utamanya. Konstruksi pada motor BLDC yaitu armature terdapat pada stator dan magnet permanen terdapat pada rotor. Pengoperasian motor ini mirip dengan motor DC yaitu menggunakan sumber utama berupa tegangan DC [2].

Motor brushless direct current dengan jenis aksial fluks merupakan jenis motor yang paling cocok digunakan pada kendaraan listrik. Keunggulan dari motor brushless direct current aksial fluks adalah dimensi dari konstruksinya relatif lebih kecil dibandingkan dengan kontruksi motor jenis lainnya, sehingga motor brushless direct current aksial fluks sangat tepat digunakan di ruangan yang terbatas. Konstruksi motor brushless direct current aksial fluks pada dasarnya terdiri dari sebuah piringan rotor yang dapat berputar dengan beberapa magnet yang menempel di dalam piringin rotor dan bagian stator yang berisi kumparan dengan inti konduktor pada slotslot stator. Diantara stator dan rotor terdapat celah yang biasa disebut dengan air gap. Celah udara ini dapat dapat mempengaruhi nilai kecepatan dan torsi yang dihasilkan oleh motor brushless direct current.

Pada penelitian sebelumnya tahun 2017 oleh Maulana, yang berjudul "Efek Air gap pada Rancang Bangun dan Uji Performa Generator Listrik Aksial berbasis Magnet Permanen NdFeB" menggunakan desain generator listrik fluks aksial yang terdiri dari dua bagian yaitu satu stator dan dua rotor. Pada penelitian tersebut menganalisis mengenai efek air gap terhadap performa generator listrik fluks aksial dengan menggunakan magnet $\mathrm{NdFeB}$. Analisis dilakukan dengan mengukur tegangan keluaran dari generator listrik terhadap ukuran air gap dan kecepatan putar rotor. [3]

Dengan topik yang sama yaitu efek air gap, penelitian ini akan menganalisis mengenai pengaruh dari air gap yang digunakan terhadap keluaran motor brushless direct current 3 fasa fluks aksial stator ganda. Motor brushless direct current yang digunakan yaitu motor brushless direct current 3 fasa fluks aksial stator ganda yang mengacu pada laporan penelitian tahun 2019 oleh Hadi, yang berjudul "Rancang Bangun dan Analisis Driver Motor BLDC Konstruksi Axial 3 Fasa". [4]

\section{METODE}

\section{A. Alat dan Bahan}


Pada penelitian ini, bahan dari rotor yang digunakan yaitu akrilik dan magnet neodymium $15 \times 2 \mathrm{~mm}$. Sedangkan bahan dari stator yaitu akrilik, spul logam, baut, bearing 625-RS dan kawat email $0.5 \mathrm{~mm}$. Alat yang digunakan untuk melakukan pengujian terdiri dari Multimeter Digital Krisbow Tipe Bench, Multimeter Digital Sanwa CD800a, Oscilloscope Hantek DSO5102P (2 Channels), Tachometer Counter Extech 461920 dan Power Supply CODY 3005DT (30V-5A).

\section{B. Diagram Alir}

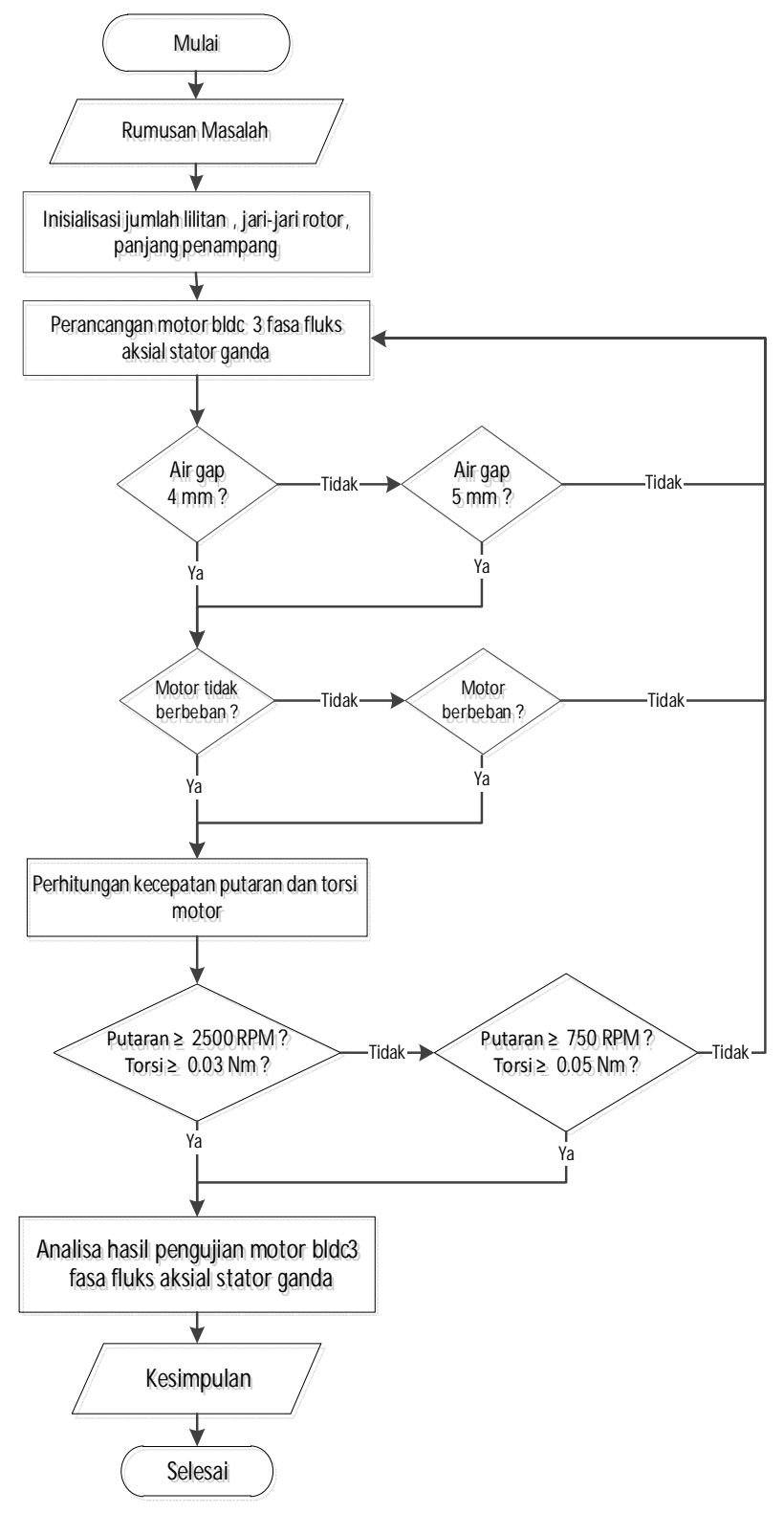

Gambar 1: Flowchart Penelitian

\section{Desain Alat}

Desain rotor pada motor ini terbuat dari akrilik berbentuk piringan dengan jari-jari rotor sebesar $3.2 \mathrm{~cm}$ dan ketebalan 2 $\mathrm{mm}$. Jumlah magnet neodymium yang digunakan pada rotor sebanyak 8 buah dengan ukuran magnet sebesar $15 \times 2 \mathrm{~mm}$. Desain rotor tersebut dapat dilihat pada Gambar 2.
Desain stator pada motor ini berbentuk kotak yang terbuat dari akrilik dengan ukuran $8 \times 8 \mathrm{~cm}$ dan ketebalan $5 \mathrm{~mm}$. Motor ini menggunakan dua stator dengan kumparan sebanyak 6 kutub tiap stator. Masing-masing kumparan terdiri dari 150 lilitan dengan diameter kawat email $5 \mathrm{~mm}$. Desain stator pada motor ini dapat dilihat pada Gambar 3.

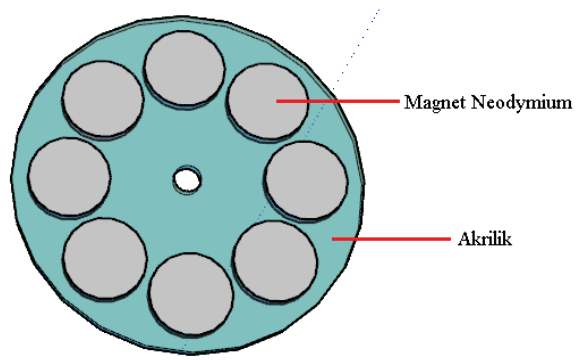

Gambar 2: Desain 3D rotor motor BLDC 3 fasa fluks aksial stator ganda

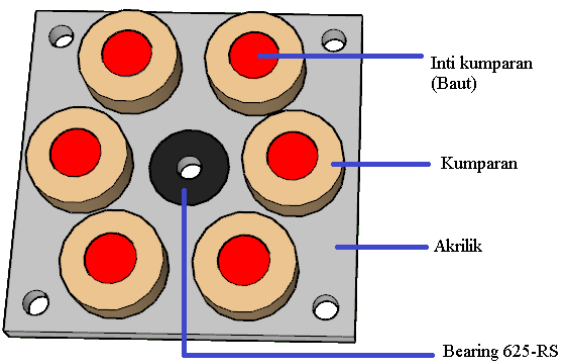

Gambar 3: Desain 3D stator motor BLDC 3 fasa fluks aksial stator ganda

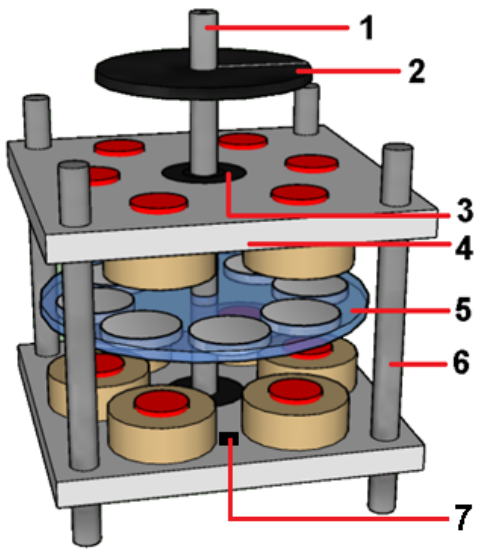

Gambar 4: Desain 3D keseluruhan motor BLDC 3 fasa fluks aksial stator ganda

Dari Gambar 4. dapat dijelaskan mengenai bagian-bagian dari motor BLDC 3 fasa fluks aksial stator ganda sebagai berikut.
1. Inti Besi
2. Encoder
3. Bearing 625-RS
4. Stator
5. Rotor
6. Baut
7. Sensor Hall Effect

D. Metode Pengumpulan Data 
Pada penelitian ini, pengujian motor BLDC fluks aksial stator ganda dilakukan ketika motor tidak diberi beban dan ketika motor diberi beban. Metode yang digunakan pada penelitian ini terdiri dari dua cara yaitu menggunakan pengukuran dan perhitungan.

\section{1) Pengukuran}

Pada tahap ini, pengujian motor BLDC fluks aksial stator ganda dilakukan dengan memvariasikan air gap sebesar $4 \mathrm{~mm}$ dan $5 \mathrm{~mm}$, dengan tegangan sumber $12 \mathrm{~V}, 13 \mathrm{~V}, 14 \mathrm{~V}$ dan $15 \mathrm{~V}$ yang berasal dari power supply. Alat ukur yang digunakan dalam melakukan pengujian terdiri dari Multimeter Digital, Ossiloscope, Tachometer dan Teslameter. Data yang diambil pada saat pengukuran terdiri dari medan magnet, tegangan masukkan motor, arus masukkan motor, frekuensi dan kecepatan putaran motor.

\section{2) Perhitungan}

Pada tahap ini, perhitungan dilakukan dengan menggunakan hasil data dari pengukuran. Parameter yang dihasilkan dari perhitungan terdiri dari kecepatan putaran motor, daya masukkan motor, torsi motor dan gaya tolak menolak.

Untuk menghitung nilai dari kecepatan putaran motor dapat menggunakan persamaan (1) sebagai berikut.

$$
n_{r}=\frac{120 f}{p}
$$

Dimana:

$$
\begin{array}{ll}
n_{r} & =\text { Kecepatan putaran motor } \\
f & =\text { Frekuensi } \\
p & =\text { Jumlah pole }
\end{array}
$$

(RPM)

Dari hasil pengukuran berupa tegangan masukkan motor dan arus masukkan motor, maka dapat dihitung daya masukkan motor dengan menggunakan persamaan (2) sebagai berikut.

$$
P=\sqrt{3} \cdot V \cdot I
$$

Dimana:

$$
\begin{array}{ll}
V & =\text { Tegangan masukkan motor } \\
I & =\text { Arus masukkan motor } \\
P & =\text { Daya }
\end{array}
$$

(volt) (ampere) (watt)
Dengan menggunakan nilai pengukuran arus masukkan motor, jumlah lilitan, medan magnet pada magnet neodymium, air gap dan panjang penampang maka dapat dihitung gaya tolak menolak yang terjadi pada motor dengan menggunakan persamaan (4) sebagai berikut.

$$
F=\frac{4 \pi i N B_{\text {magnet }} x^{2}}{L}
$$

Dimana:

$$
\begin{array}{ll}
F & =\text { Gaya tolak menolak } \\
B & =\text { Medan magnet } \\
i & =\text { Kuat arus listrik } \\
l & =\text { Panjang penampang } \\
N & =\text { Jumlah lilitan } \\
x & =\text { Air gap }
\end{array}
$$

Dari dimensi rotor dan perhitungan gaya tolak menolak, maka dapat dihitung nilai torsi dengan menggunakan persamaan (5) sebagai berikut.

$$
T=F \cdot r
$$

$$
\text { Dimana: }
$$

$$
\begin{array}{lll}
T & =\text { Torsi } & (\mathrm{Nm}) \\
F & =\text { Gaya } & (\mathrm{N}) \\
r & =\text { Jari-jari pada rotor } & (\mathrm{m})
\end{array}
$$

Dari hasil perhitungan dan pengukuran kecepatan putaran motor, maka dapat dihitung error persen menggunakan persamaan (6) berikut.

$$
E \%=\left|\frac{H_{\text {hitung }}-H_{\text {ukur }}}{H_{\text {hitung }}}\right| \times 100 \%
$$

Dimana:

$$
\begin{array}{ll}
\mathrm{H}_{\text {hitung }} & =\text { Hasil perhitungan kecepatan } \\
\mathrm{H}_{\text {ukur }} & =\text { Hasil pengukuran kecepatan }
\end{array}
$$

\begin{tabular}{|c|c|c|c|c|c|c|}
\hline $\begin{array}{c}\text { Keadaan } \\
\text { Motor }\end{array}$ & $\begin{array}{c}\text { Air } \\
\text { gap } \\
(\mathrm{mm})\end{array}$ & $\begin{array}{c}\text { Tegangan } \\
\text { sumber } \\
\text { (volt) }\end{array}$ & $\begin{array}{c}\text { Tegangan } \\
\text { masukkan } \\
\text { motor (volt) }\end{array}$ & $\begin{array}{c}\text { Arus } \\
\text { masukkan } \\
\text { motor } \\
\text { (ampere) }\end{array}$ & $\begin{array}{c}f \\
(\mathbf{H z})\end{array}$ & $\begin{array}{c}\text { Putaran } \\
\text { motor } \\
\text { ukur } \\
\text { (RPM) }\end{array}$ \\
\hline \multirow{8}{*}{$\begin{array}{c}\text { Motor } \\
\text { Tidak } \\
\text { Berbeban }\end{array}$} & \multirow{4}{*}{4} & 12 & 8.460 & 1.240 & 260 & 3852 \\
\hline & & 13 & 9.157 & 1.280 & 284 & 4261 \\
\hline & & 14 & 9.927 & 1.290 & 312 & 4711 \\
\hline & & 15 & 10.683 & 1.290 & 333 & 4976 \\
\hline & \multirow{4}{*}{5} & 12 & 8.607 & 0.96 & 373 & 5551 \\
\hline & & 13 & 9.380 & 0.97 & 400 & 6023 \\
\hline & & 14 & 10.047 & 0.99 & 423 & 6427 \\
\hline & & 15 & 10.813 & 1.01 & 454 & 6887 \\
\hline \multirow{8}{*}{$\begin{array}{c}\text { Motor } \\
\text { Berbeban } \\
\text { (Resistor } \\
50 \mathrm{ohm} \text { ) }\end{array}$} & \multirow{4}{*}{4} & 12 & 7.467 & 3.150 & 70 & 1057 \\
\hline & & 13 & 7.957 & 3.170 & 72 & 1070 \\
\hline & & 14 & 8.673 & 3.230 & 82 & 1247 \\
\hline & & 15 & 9.490 & 3.330 & 88 & 1334 \\
\hline & \multirow{4}{*}{5} & 12 & 6.980 & 3.24 & 60 & 899 \\
\hline & & 13 & 7.800 & 3.43 & 65 & 989 \\
\hline & & 14 & 8.607 & 3.56 & 78 & 1173 \\
\hline & & 15 & 9.440 & 3.68 & 84 & 1271 \\
\hline
\end{tabular}

\section{HASIL DAN PEMBAHASAN}

Pengujian pada motor BLDC dilakukan dengan cara mengukur keluaran dari motor. Pengujian dilakukan dengan menggunakan air gap $4 \mathrm{~mm}$ dan $5 \mathrm{~mm}$, ketika motor tidak berbeban dan ketika motor berbeban. Air gap yang digunakan pada motor ini sebesar $4 \mathrm{~mm}$ dan $5 \mathrm{~mm}$. Hal itu dikarenakan jika air gap yang digunakan kurang dari sama dengan $4 \mathrm{~mm}$, terdapat gesekan antara rotor dan stator saat rotor berputar karena posisi rotor dan stator yang terlalu dekat. Dan ketika air gap yang digunakan lebih dari $5 \mathrm{~mm}$, arus yang muncul pada power supply mendekati nilai 4 ampere, sedangkan arus maksimal dari power supply yang digunakan sebesar 5 ampere. Dari hasil pengukuran tersebut akan dilakukan perbandingan mengenai hasil keluaran dari motor BLDC. Parameter yang akan dibandingkan terdiri dari tegangan motor, arus motor, frekuensi dan kecepatan putaran motor. Pada pembahasan ini dilakukan perbandingan hasil pengukuran ketika motor tidak berbeban dan ketika motor diberi beban resistor $50 \mathrm{ohm}$.

TABEL I

PERBANDINGAN HASIL PENGUKURAN KETIKA MOTOR TIDAK DAN MOTOR BERBEBAN RESISTOR 50 OHM

Dari Tabel 1 dapat dilihat bahwa tegangan masukkan motor, frekuensi dan kecepatan putaran motor yang dihasilkan 
ketika motor tidak berbeban memiliki nilai yang lebih besar dibandingkan ketika motor berbeban. Sedangkan arus motor pada saat motor berbeban memiliki nilai yang lebih besar dibandingkan pada saat motor tidak berbeban. Pada motor tidak berbeban, semakin besar air gap yang digunakan, maka tegangan motor, frekuensi dan kecepatan putaran motor juga semakin meningkat sedangkan arus motor semakin menurun. Pada motor berbeban, semakin besar air gap yang digunakan, maka tegangan motor, frekuensi dan kecepatan putaran motor semakin menurun, sedangkan arus motor semakin meningkat.

Pada motor BLDC, tegangan masukkan motor pada saat motor tidak berbeban memiliki nilai yang lebih tinggi dibandingkan pada saat motor berbeban. Nilai tertinggi dari tegangan masukkan motor terletak pada saat motor tidak berbeban dengan air gap $5 \mathrm{~mm}$. Pada pengujian motor tanpa beban, nilai tegangan masukkan motor ketika air gap $5 \mathrm{~mm}$ memiliki nilai yang lebih tinggi dibandingkan dengan air gap $4 \mathrm{~mm}$. Namun ketika pengujian motor dengan menggunakan beban, nilai tegangan masukkan motor ketika air gap $4 \mathrm{~mm}$ memiliki nilai yang lebih besar dibandingkan dengan air gap $5 \mathrm{~mm}$. Grafik hubungan tegangan sumber terhadap tegangan masukkan motor dapat dilihat pada Gambar 5.

Pada motor BLDC, arus masukkan motor pada saat motor berbeban memiliki nilai yang lebih tinggi dibandingkan pada saat motor tidak berbeban. Nilai tertinggi dari arus masukkan motor terletak pada saat motor berbeban dengan air gap 5 mm. Pada pengujian motor tanpa beban, nilai arus masukkan motor ketika air gap $4 \mathrm{~mm}$ memiliki nilai yang lebih tinggi dibandingkan dengan air gap $5 \mathrm{~mm}$. Namun ketika pengujian motor dengan menggunakan beban, nilai arus masukkan motor ketika air gap $5 \mathrm{~mm}$ memiliki nilai yang lebih besar dibandingkan dengan air gap $4 \mathrm{~mm}$. Grafik hubungan tegangan sumber terhadap arus masukkan motor dapat dilihat pada Gambar 6.

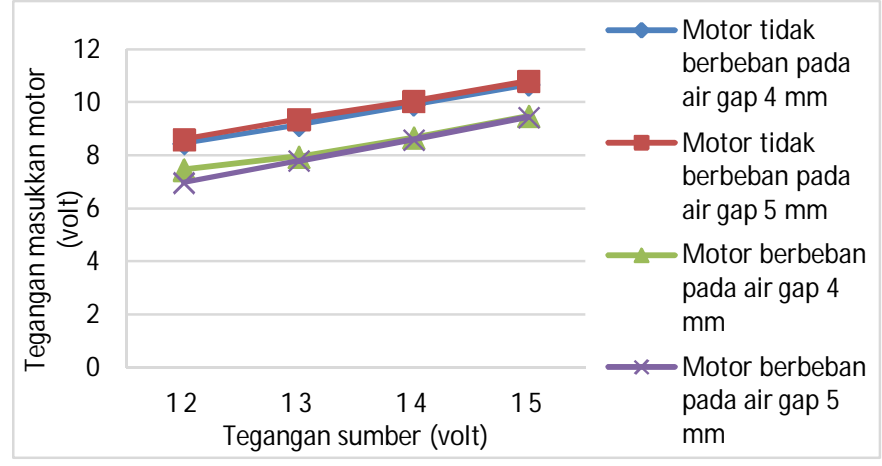

Gambar 5: Grafik hubungan tegangan sumber terhadap tegangan motor ketikamotor tidak berbeban dan ketika motor berbeban

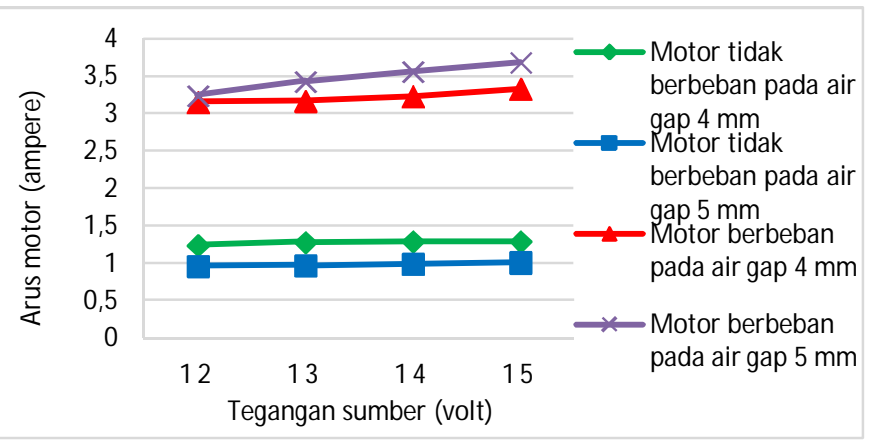

Gambar 6: Grafik hubungan tegangan sumber terhadap arus motor ketika motor tidak berbeban dan ketika motor berbeban

TABEL II

PERHITUNGAN KELUARAN MOTOR KETIKA MOTOR TIDAK BERBEBAN DAN KETIKA MOTOR DIBERI BEBAN RESISTOR 50 OHM

\begin{tabular}{|c|c|c|c|c|c|c|}
\hline $\begin{array}{c}\text { Keadaan } \\
\text { Motor }\end{array}$ & $\begin{array}{c}\text { Air } \\
\text { gap } \\
(\mathrm{mm})\end{array}$ & $\begin{array}{c}\text { Teganga } \\
\text { n } \\
\text { sumber } \\
\text { (volt) }\end{array}$ & \begin{tabular}{|c|} 
Daya \\
masukkan \\
motor \\
(watt)
\end{tabular} & \begin{tabular}{|c|} 
Gaya \\
tolak \\
menolak \\
$(\mathrm{N})$
\end{tabular} & $\begin{array}{l}\text { Torsi } \\
\text { motor } \\
(\mathrm{Nm})\end{array}$ & $\begin{array}{c}\text { Putara } \\
\mathbf{n} \\
\text { motor } \\
\text { hitung } \\
\text { (RPM) }\end{array}$ \\
\hline \multirow{8}{*}{$\begin{array}{c}\text { Motor } \\
\text { Tidak } \\
\text { Berbeban }\end{array}$} & \multirow{4}{*}{4} & 12 & 18.170 & 1.876 & 0.060 & 3900 \\
\hline & & 13 & 20.301 & 1.921 & 0.061 & 4260 \\
\hline & & 14 & 22.180 & 1.951 & 0.062 & 4680 \\
\hline & & 15 & 23.870 & 1.951 & 0.062 & 4995 \\
\hline & \multirow{4}{*}{5} & 12 & 14.311 & 1.689 & 0.054 & 5595 \\
\hline & & 13 & 15.759 & 1.706 & 0.055 & 6000 \\
\hline & & 14 & 17.227 & 1.741 & 0.056 & 6345 \\
\hline & & 15 & 18.917 & 1.776 & 0.057 & 6810 \\
\hline \multirow{8}{*}{$\begin{array}{l}\text { Motor } \\
\text { Berbeban } \\
\text { (Resistor } \\
50 \mathrm{ohm} \text { ) }\end{array}$} & \multirow{4}{*}{4} & 12 & 40.738 & 4.765 & 0.152 & 1050 \\
\hline & & 13 & 43.687 & 4.795 & 0.153 & 1080 \\
\hline & & 14 & 48.523 & 4.886 & 0.156 & 1230 \\
\hline & & 15 & 54.736 & 5.037 & 0.161 & 1320 \\
\hline & \multirow{4}{*}{5} & 12 & 39.171 & 5.699 & 0.182 & 900 \\
\hline & & 13 & 46.339 & 6.033 & 0.193 & 975 \\
\hline & & 14 & 53.070 & 6.262 & 0.200 & 1170 \\
\hline & & 15 & 60.170 & 6.473 & 0.207 & 1260 \\
\hline
\end{tabular}

Dari Tabel 2 dapat dilihat bahwa nilai dari daya motor, torsi motor dan gaya tolak menolak yang dihasilkan pada saat motor diberi beban memiliki nilai yang lebih besar dibandingkan dengan pada saat motor tidak berbeban. Pada motor tidak berbeban, semakin besar air gap yang digunakan maka nilai daya motor, torsi motor dan gaya tolak menolak motor semakin turun. Namun pada saat motor diberi beban, nilai daya motor dan torsi motor semakin naik, sedangkan nilai gaya tolak menolak motor semakin turun.

Dari hasil perhitungan, nilai dari daya masukkan motor pada saat motor berbeban memiliki nilai yang lebih tinggi dibandingkan pada saat motor tidak berbeban. Nilai tertinggi dari daya masukkan motor terletak pada saat motor berbeban dengan air gap $5 \mathrm{~mm}$. Pada pengujian motor tanpa beban, nilai daya masukkan motor ketika air gap $4 \mathrm{~mm}$ memiliki nilai yang lebih tinggi dibandingkan dengan air gap $5 \mathrm{~mm}$. Namun ketika pengujian motor dengan menggunakan beban, nilai daya masukkan motor ketika air gap $5 \mathrm{~mm}$ memiliki nilai yang lebih besar dibandingkan dengan air gap $4 \mathrm{~mm}$. Grafik hubungan tegangan sumber terhadap daya masukkan motor dapat dilihat pada Gambar 7.

Dari hasil perhitungan, nilai gaya tolak menolak pada saat motor berbeban memiliki nilai yang lebih tinggi dibandingkan pada saat motor tidak berbeban. Nilai tertinggi dari gaya tolak menolak motor terletak pada saat motor berbeban dengan air gap $4 \mathrm{~mm}$. Pada pengujian motor tanpa beban, nilai gaya tolak menolak motor ketika air gap $4 \mathrm{~mm}$ memiliki nilai yang lebih tinggi dibandingkan dengan air gap $5 \mathrm{~mm}$. Namun ketika pengujian motor dengan menggunakan beban, nilai gaya tolak menolak motor ketika air gap $4 \mathrm{~mm}$ memiliki nilai yang lebih besar dibandingkan dengan air gap $5 \mathrm{~mm}$. Perbedaan nilai 
Majalah Ilmiah Teknologi Elektro, Vol. 19, No. 2, Juli-Desember 2020

DOI: https://doi.org/10.24843/MITE.2020.v19i02.P10

gaya tolak menolak motor ketika motor tidak berbeban dengan motor berbeban resistor $50 \mathrm{ohm}$ terjadi cukup jauh. Hal itu dikarenakan terjadi lonjakan arus yang siginifikan pada motor berbeban dan perbedaan nilai medan magnet. Grafik hubungan tegangan sumber terhadap gaya tolak menolak dapat dilihat pada Gambar 8.

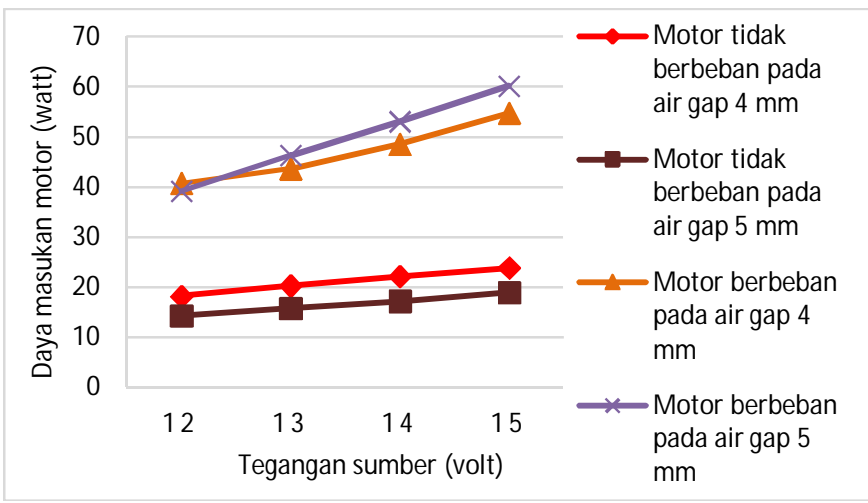

Gambar 7: Grafik hubungan tegangan sumber terhadap daya masukkan motor ketika motor tidak berbeban dan ketika motor berbeban

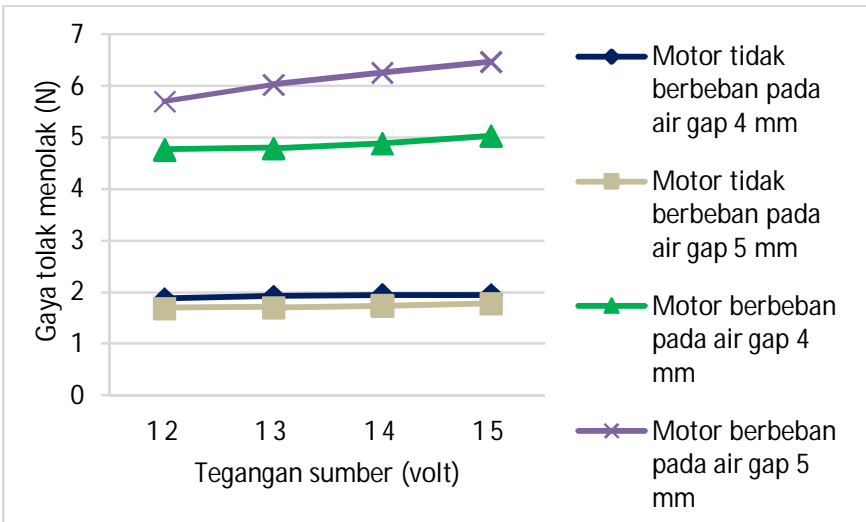

Gambar 8: Grafik hubungan tegangan sumber terhadap daya masukkan motor ketika motor tidak berbeban dan ketika motor berbeban

Dari hasil perhitungan,nilai dari kecepatan putaran motor pada saat motor tidak berbeban memiliki nilai yang lebih tinggi dibandingkan pada saat motor berbeban. Nilai tertinggi dari kecepatan putaran motor terletak pada saat motor tidak berbeban dengan air gap $5 \mathrm{~mm}$. Pada pengujian motor tanpa beban, nilai kecepatan putaran motor ketika air gap $4 \mathrm{~mm}$ memiliki nilai yang lebih rendah dibandingkan dengan air gap $5 \mathrm{~mm}$. Namun ketika pengujian motor dengan menggunakan beban, nilai kecepatan putaran motor ketika air gap $5 \mathrm{~mm}$ dan air gap $4 \mathrm{~mm}$ memiliki selisih yang kecil. Perbedaan nilai kecepatan putaran motor ketika motor tidak berbeban dengan motor berbeban resistor $50 \mathrm{ohm}$ terjadi cukup besar. Hal itu dikarenakan ketika motor diberi beban maka untuk mencapai 1 putaran membutuhkan waktu yang lebih lama sehingga frekuensinya lebih kecill dibandingkan pada saat motor tidak diberi beban. Grafik hubungan tegangan sumber terhadap kecepatan putaran motor dapat dilihat pada Gambar 9.

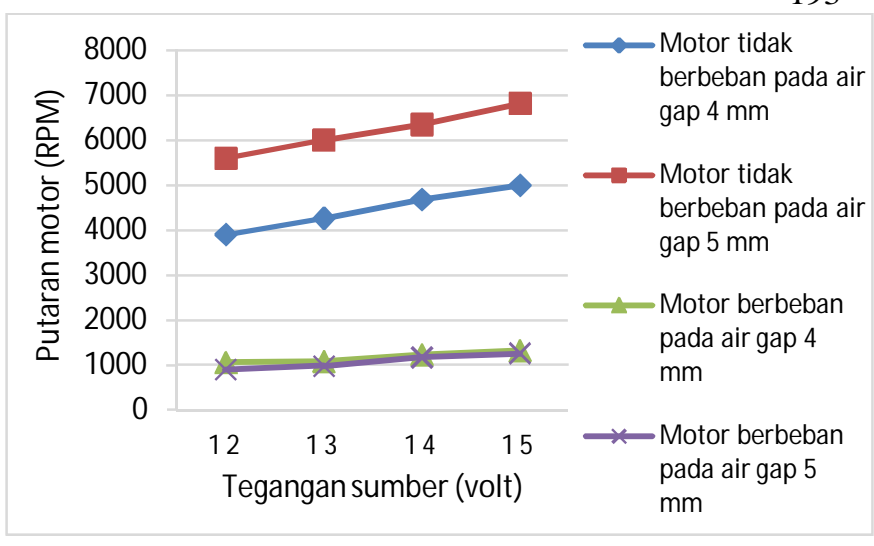

Gambar 9. Grafik hubungan tegangan sumber terhadap kecepatan putaran motor ketika motor tidak berbeban dan ketika motor berbeban

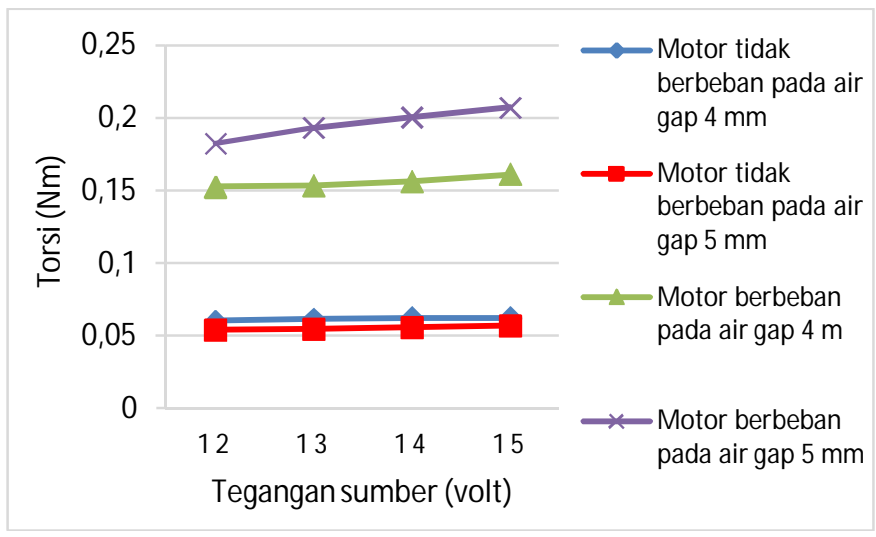

Gambar 10: Grafik hubungan tegangan sumber terhadap torsi motor ketika motor tidak berbeban dan ketika motor berbeban

Dari Gambar 10 dapat dilihat bahwa nilai dari torsi motor pada saat motor berbeban memiliki nilai yang lebih tinggi dibandingkan pada saat motor tidak berbeban. Nilai tertinggi dari torsi motor terletak pada saat motor berbeban dengan air gap $5 \mathrm{~mm}$. Pada pengujian motor tanpa beban, nilai torsi motor ketika air gap $4 \mathrm{~mm}$ memiliki nilai yang lebih tinggi dibandingkan dengan air gap $5 \mathrm{~mm}$. Namun ketika pengujian motor dengan menggunakan beban, nilai torsi motor ketika air gap $5 \mathrm{~mm}$ memiliki nilai yang lebih besar dibandingkan dengan air gap $4 \mathrm{~mm}$. Perbedaan nilai torsi motor ketika motor tidak berbeban dengan motor berbeban resistor $50 \mathrm{ohm}$ terjadi cukup besar. Hal itu dikarenakan terjadi lonjakan arus masukkan motor yang siginifikan pada saat motor berbeban.

\section{KESIMPULAN}

Dari penelitian yang telah dilakukan, dapat disimpulkan sebagai beikut.

1. Dalam pengujian kecepatan putaran motor brushless direct current tanpa menggunakan beban, ketika air gap yang digunakan semakin besar maka kecepatan putaran yang dihasilkan juga semakin besar. Misalnya pada tegangan sumber 12 volt ketika air gap yang digunakan $4 \mathrm{~mm}$, kecepatan motor yang dihasilkan sebesar 3852 RPM. Namun ketika air gap yang digunakan menjadi $5 \mathrm{~mm}$, 
kecepatan motor yang dihasilkan sebesar 5551 RPM. Sehingga ketika air gap dinaikkan dari $4 \mathrm{~mm}$ ke $5 \mathrm{~mm}$ terjadi kenaikkan nilai kecepatan putaran motor sebesar 1699 RPM.

2. Dalam pengujian torsi motor brushless direct current tanpa menggunakan beban, ketika air gap yang digunakan semakin besar maka torsi yang dihasilkan semakin kecil. Misalnya saat tegangan sumber 12 volt ketika air gap yang digunakan $4 \mathrm{~mm}$, torsi motor yang dihasilkan sebesar $0.045 \mathrm{Nm}$. Namun ketika air gap yang digunakan menjadi $5 \mathrm{~mm}$, torsi yang dihasilkan sebesar $0.025 \mathrm{Nm}$. Sehingga ketika air gap dinaikkan dari $4 \mathrm{~mm}$ ke $5 \mathrm{~mm}$ terjadi penurunan nilai torsi motor sebesar $0.02 \mathrm{Nm}$.

3. Pada pengujian kecepatan putaran motor brushless direct current dengan menggunakan beban resistor $50 \mathrm{ohm}$, ketika air gap yang digunakan semakin besar maka kecepatan putaran motor yang dihasilkan semakin kecil. Misalnya saat tegangan sumber 12 volt, ketika air gap yang digunakan $4 \mathrm{~mm}$, kecepatan motor yang dihasilkan sebesar 1057 RPM. Namun ketika air gap yang digunakan menjadi $5 \mathrm{~mm}$, kecepatan motor yang dihasilkan sebesar 900 RPM. Sehingga ketika air gap dinaikkan dari $4 \mathrm{~mm}$ ke $5 \mathrm{~mm}$ terjadi penurunan nilai kecepatan putaran motor sebesar 157 RPM.

4. Pada pengujian torsi motor brushless direct current dengan menggunakan beban resistor $50 \mathrm{ohm}$, ketika air gap yang digunakan semakin besar maka torsi yang dihasilkan juga semakin besar. Misalnya saat tegangan sumber 12 volt, ketika air gap yang digunakan $4 \mathrm{~mm}$, torsi motor yang dihasilkan sebesar $0.368 \mathrm{Nm}$. Namun ketika air gap yang digunakan menjadi $5 \mathrm{~mm}$, torsi motor yang dihasilkan sebesar $0.416 \mathrm{Nm}$. Sehingga ketika air gap dinaikkan dari $4 \mathrm{~mm}$ ke $5 \mathrm{~mm}$ terjadi kenaikan nilai torsi motor sebesar $0.048 \mathrm{Nm}$.

\section{REFERENSI}

[1] APRESCO, R. A. D. 2017. Perbandingan unjuk kerja notor brushless direct current dan brushed dc pada nogogeni urban konsep. 0:1-71.

[2] Budijanto, A. 2018. Pengaturan kecepatan motor dc pada robot line follower menggunakan pulse width modulation (pwm). Senasif. 2-2.

[3] Fallis, A. 2013. Bab ii landasan teori. Journal of Chemical Information and Modeling. 53(9):1689-1699.

[4] Giancoli, D. C. 2001. FISIKA. Edisi ke-5. Jakarta: Erlangga.

[5] Giulietti dan Assumpção. 2019. 済無 No Title No Title. 9. Journal of Chemical Information and Modeling.

[6] Hadi, Widyono., G. Aditya Rahardi, D. Ayu Larasati, M. Gozali, dan S. Bachri Masmachofari. 2019. Rancang Bangun dan Analisis Driver Motor BLDC Konstruksi Axial 3 Fasa. Laporan Penelitian

[7] Hughes, A. dan B. Drury. 2013. Electric Motors and Drives. Electric Motors and Drives.

[8] Jearl Walker. 2014. Fundamentals of Physics Halliday \& Resnick 10ed. Wiley.

[9] JST UK. 2018. Wire size and current rating. 3:1.

[10] Maulana, A. 2017. Efek air gap pada rancang bangun dan uji performa generator listrik fluks aksial berbasis magnet permanen ndfeb. PISTON: Journal of Technical Engineering. 1(1):6-12.

[11] Parviainen, A. 2005. Design of Axial-Flux Permanent-Magnet LowSpeed Machines and Performance Comparison Between Radial-Flux and Axial-Flux Machines. Thesis.

[12] Pratama, F. dan E. 2018. Rancang bangun pengendalian kecepatan brushless dc motor tipe a2212/10t $1400 \mathrm{kv}$ menggunakan kontroler pid berbasis labview. Jurnal Teknik Elektro. 7(03):157-166.

[13] Putra, R. A. W., E. Firmansyah, dan F. Danang Wijaya. 2014. Metode six step comutation pada perancangan rangkian kendali sensored motor brushless direct current. Jurnal Penelitian Teknik Elektro Dan Teknik Informasi. 1(1):46-50.

[14] Shewane, P. G., M. Gite, A. Singh, dan A. Narkhede. 2014. An overview of neodymium magnets over normal magnets for the generation of energy. International Journal on Recent and Innovation Trends in Computing and Communication. 2(12):4056-4059.

[15] Siswoyo. 2008. Teknik Listrik Industri. PhD Proposal. 